\title{
Calcareous dinoflagellate turnover in relation to the Messinian salinity crisis in the eastern Mediterranean Pissouri Basin, Cyprus
}

\author{
KATARZYNA-MARIA BISON ${ }^{1}$, GERARD J.M. VERSTEEGH ${ }^{2}$, FRITS J. HILGEN ${ }^{3}$ \& HELMUT WILLEMS ${ }^{1}$ \\ ${ }^{1}$ Division of Palaeontology, University of Bremen, FB 5, Geowissenschaften, Postfach 330440, D-28334 Bremen, Germany \\ (e-mail: kbison@uni-bremen.de) \\ ${ }^{2}$ Institut für Biogeochemie und Meereschemie, Universität Hamburg, Bundesstraße 55, D-20146 Hamburg, Germany \\ ${ }^{3}$ University of Utrecht, Faculty of Earth Sciences, Budapestlaan 4, 3594 Utrecht, Netherlands
}

\begin{abstract}
The extent to which the Messinian salinity crisis modified the initially Tethyan, eastern Mediterranean phytoplankton community has been investigated by monitoring the fate of calcareous dinoflagellate cyst assemblages prior to, during and after the salinity crisis in the Pissouri section (Cyprus). A rich, but low diversity open oceanic assemblage, dominated by Calciodinellum albatrosianum, is found in the upper Tortonian and lower Messinian. The upper Messinian (pre-evaporitic) sediments yield only few cysts but the assemblage is much more diverse and reflects unstable more neritic conditions (Bicarinellum tricarinelloides), fluvial influence (Leonella granifera) and varying, temporally increased salinities (Pernambugia tuberosa), probably related to the increasingly restricted environment. The basal Pliocene sediments reflect the return to normal marine conditions; the dinoflagellate assemblage is rich in cysts and again has a low diversity. However, in contrast to the C. albatrosianum-dominated upper Tortonian and pre-evaporitic Messinian sediments, L. granifera clearly dominates the basal Pliocene association just after the replenishment of the Mediterranean basin. Apart from this shift in dominance, the onset of the Pliocene is furthermore marked by the first appearance of Calciodinellum elongatum, which must have immigrated from the Atlantic Ocean. Lebessphaera urania, a postulated remnant of the Tethyan Ocean survived the salinity crisis, possibly in as yet unidentified marine refuges in the Mediterranean itself. Although the environmental changes caused by the Messinian salinity crisis did not lead to an extinction of calcareous dinoflagellate species of the Pissouri Basin, it resulted in a significant change in the assemblages and contributed to a more modern character of the Pliocene dinoflagellate association in the eastern Mediterranean. J. Micropalaeontol. 26(2): 103-116, October 2007.
\end{abstract}

KEYWORDS: Messinian, calcareous dinoflagellates, Mediterranean, Pliocene, Miocene

\section{INTRODUCTION}

The dramatic drop in sea-level of the Mediterranean Basin during the Messinian salinity crisis represents a major environmental breakdown within an oceanic basin. It led to extensive and widespread evaporite deposition underlying the modern Mediterranean Sea (e.g. Hsü et al., 1973, 1977; Hsü, 1978; Butler et al., 1999; Lofi et al., 2005; Meijer \& Krijgsman, 2005; Tay et al., 2002). These evaporites reflect the progressive closure of the Mediterranean gateways, which resulted in the almost complete isolation of the Mediterranean from the Atlantic Ocean during the final stage of the Messinian salinity crisis (Hsü \& Bernoulli, 1978; Krijgsman et al., 1999; Bianchi \& Morri, 2000; Seidenkrantz et al., 2000; Blanc, 2002; Manzi et al., 2005; Matano et al., 2005).

Considering that the Mediterranean Sea is an old Tethys remnant, it is a natural heir to the Tethyan biodiversity (Bianchi \& Morri, 2000; Bouillon et al., 2004). Despite the connection between the Atlantic and the Mediterranean, one may expect that migration of Atlantic species into the Mediterranean must have been largely restricted to those niches not already occupied by the Tethys biota. The Messinian salinity crisis may have changed this. The drastic environmental changes during the salinity crisis caused by the significant fall in sea-level (e.g. Loget et al., 2006) must have wiped out, or diminished, many taxa (Bouchet \& Taviani, 1992; Bianchi \& Morri, 2000; Seidenkrantz et al., 2000; Logan et al., 2004; Domingues et al., 2005; Kouwenhoven et al., 2006). In the Mediterranean, the relatively stable open oceanic environment probably disappeared completely, in contrast to the neritic realms, which in part experienced a displacement only (Keogh \& Butler, 1999; Bianchi \& Morri, 2000). Therefore, oceanic extinction must have been most severe (Bianchi \& Morri, 2000; Logan et al., 2004); in particular, a remarkable decrease was recognized for deep-water representatives of most phyla (Seidenkrantz et al., 2000; Emig \& Geistdoerfer, 2004; Kouwenhoven et al., 2006). After the crisis, the vacant niches will have been refilled by species migrating or re-migrating from the Atlantic into the Mediterranean (Bianchi \& Morri, 2000; Logan et al., 2004). An important biogeographical question is attached to this event: how and to what extent did the originally Tethyan marine biota survive this crisis and to what extent were they replaced by newcomers from the adjacent Atlantic?

Calcareous dinoflagellates could provide an important insight into the development of the Messinian environmental change and its biogeographical effects since they are sensitive to salinity, nutrient and temperature changes and they have representatives in the entire spectrum of marine environments, from open marine to estuarine (e.g. Dale, 1992; Höll et al., 1998, 1999; Zonneveld et al., 1999; Höll \& Kemle-von Mücke, 2000; Wendler et al., 2002a, b, c; Meier \& Willems, 2003; Tanimura \& Shimada, 2004; Vink, 2004; Kohring et al., 2005).

Unfortunately, information on Miocene and Pliocene calcareous dinoflagellate assemblages from this region is very sparse. Comparison of the associations from the few investigated 
localities from the Mediterranean area (Keupp \& Kohring, 1993, 1999; Kohring, 1993b, 1997; Keupp et al., 1994) shows strong changes in cyst abundance but only little variability in species diversity and composition. On the basis hereof, an alternative scenario to that postulated above has been proposed: namely a permanent input of oceanic species from the Atlantic into the Mediterranean during the Miocene-Pliocene which kept the oceanic assemblages of the Atlantic and Mediterranean more or less identical (Keupp \& Kohring, 1993, 1999; Kohring, 1993b). In this scenario, the Messinian salinity crisis is supposed to have affected the neritic species only. To shed more light on this controversy, the calcareous dinoflagellate assemblages from the eastern Mediterranean upper Miocene-lower Pliocene sedimentary succession from the Pissouri Basin of Cyprus were investigated.

\section{Modern calcareous dinoflagellates}

Calcareous dinoflagellates are primary producers and thus are restricted to the euphotic zone (e.g. Höll et al., 1999; Wendler et al., 2002b; Vink et al., 2002; Vink, 2004). In modern oceans, they often dominate the total dinoflagellate flux to the sea floor (Dale, 1992; Zonneveld et al., 1999; Vink et al., 2000). In the Mediterranean, calcareous dinoflagellates are the second most important carbonate producers after coccolithophorids, with an average of $17 \%$ of the total biogenic carbonate flux (Ziveri et al., 2000). Over the last decades, understanding of their phylogeny, biodiversity and ecology has increased greatly (e.g. Keupp \& Versteegh, 1989; Höll et al., 1998, 1999; Zonneveld et al., 1999, 2000; Karwath et al., 2000; Wendler et al., 2002b, c; Friedrich \& Meier, 2003; Gottschling \& Plötner, 2004; Meier et al., 2004; Tanimura \& Shimada, 2004; Vink, 2004; Zonneveld, 2004). This knowledge has been applied successfully to reconstruct environmental parameters such as productivity and surface water stratification (Höll et al., 1999; Höll \& Kemle-von Mücke, 2000; Esper et al., 2000; Wendler et al., 2002c; Vink, 2004; Meier et al., 2004).

\section{Mediterranean assemblages}

Mediterranean associations have been shown to differ from those of other marine environments. The apparent gradual west-east change in the Mediterranean dinoflagellate cyst assemblages is correlated strongly with the main environmental gradients in the surface waters (Meier \& Willems, 2003; Meier et al., 2004). Eastwards, salinity and temperature increase whereas nutrient concentrations decrease.

Today, Thoracosphaera heimii dominates the Mediterranean assemblages, with relative abundances $>88 \%$ and its relative abundance in the eastern Basin is usually lower than in the Western Basin (Meier \& Willems, 2003). T. heimii also dominates the Arabian Sea, Atlantic and Pacific oceans but, if one excludes $T$. heimii, the most abundant species are Calciodinellum albatrosianum, Leonella granifera, C. levantinum and Pernambugia tuberosa (e.g. Wendler et al., 2002a; Hernández-Becerril \& Bravo-Sierra, 2004; Tanimura \& Shimada, 2004; Vink, 2004). From these taxa only $C$. levantinum reaches similar high relative abundances in the western Mediterranean Sea (Meier \& Willems, 2003) which is considered to reflect an Atlantic influence through the Strait of Gibraltar (Meier \& Willems, 2003). This species is closely similar to, and has been confused with
P. tuberosa, which is one of the main species in the tropical and South Atlantic Ocean (Höll et al., 1999; Esper et al., 2000).

Lebessphaera urania is known only from the eastern Mediterranean where it dominates the dinoflagellate associations (Meier et al., 2002; Meier \& Willems, 2003). Scripsiella regalis is a frequent component in the whole Mediterranean Sea. C. albatrosianum represents only $<5 \%$ of the associations, whereas Pernambugia tuberosa (former name Sphaerodinella tuberosa) is absent (Meier \& Willems, 2003) but forms up to $75 \%$ in the South and equatorial Atlantic Ocean (Vink, 2004).

L. granifera is mostly rare to absent in Mediterranean sediments or traps (Meier \& Willems, 2003) but it reaches high relative and absolute abundances in more shelfward regions of the Atlantic Ocean and Arabian Sea where river influence and/or continental nutrient supply (dust) play a major role (Vink et al., 2000; Vink, 2004; Zonneveld et al., 2001; Wendler et al., 2002b, c; Meier et al., 2004; Tanimura \& Shimada, 2004). This species appears to be an excellent proxy for nutrient-enriched environments induced by terrigenous input (e.g. Wendler et al., 2002b, c; Meier et al., 2004; Vink, 2004).

This interpretation of L. granifera is applied to re-interpret environmental reconstructions of other Miocene and Pliocene assemblages, leading to a better understanding of past environmental settings. Until now, the fossil distribution pattern of $L$. granifera could not be related to any environmental parameter except as a general open marine species with no distinct ecological preferences (Fütterer, 1977; Keupp \& Kohring, 1993; Kohring, 1993, 1997).

\section{Palaeoenvironment of the Pissouri Basin}

The Neogene sedimentary succession on Cyprus shows a gradual shallowing from Palaeogene deep-water pelagic carbonates (Lefkara Formation) through mixed detrital sediments, carbonates and reefal limestones, to the Messinian evaporites (Orszag-Sperber et al., 1989; Robertson et al., 1995; Krijgsman et al., 2002). The Messinian evaporites on Cyprus were deposited in small sub-basins (e.g. Polemi, Psematismenos and Pissouri basins) (Orszag-Sperber et al., 1989; Robertson et al., 1995; Krijgsman et al., 2002). With the beginning of the Pliocene, deeper-water conditions were re-established (Rouchy et al., 2001; Krijgsman et al., 2002). The Messinian sedimentary succession on Cyprus is characterized by pre-evaporitic deposits, overlain by two gypsum units followed by a lagoonal-lacustrine transitional facies (Lago Mare facies) leading to the marine marls of the basal Pliocene (Rouchy et al., 2001; Krijgsman et al., 2002). A small hiatus between $5.59 \mathrm{Ma}$ and $5.52 \mathrm{Ma}$ (Carnevale et al., 2006), representing an erosive phase during the late Messinian lowstand, occurs between the upper gypsum deposits and the overlying lowermost Pliocene sediments (Orszag-Sperber et al., 2000).

Palaeodepth estimations in the Pissouri section are based on foraminifera, bivalves and gastropods (Rouchy et al., 2001; Krijgsman et al., 2002; Kouwenhoven et al., 2006). A progressive shallowing occurred from approximately $500 \mathrm{~m}$ during the Tortonian and early Messinian to very shallow-water conditions during the late Messinian. Sediments above Pissouri cycle 9 (Fig. 2) were probably deposited at depths of less than $100 \mathrm{~m}$ (Krijgsman et al., 2002). Gypsum and its pseudomorphs already occur sporadically above cycle 22 (Fig. 2), with an increasing 


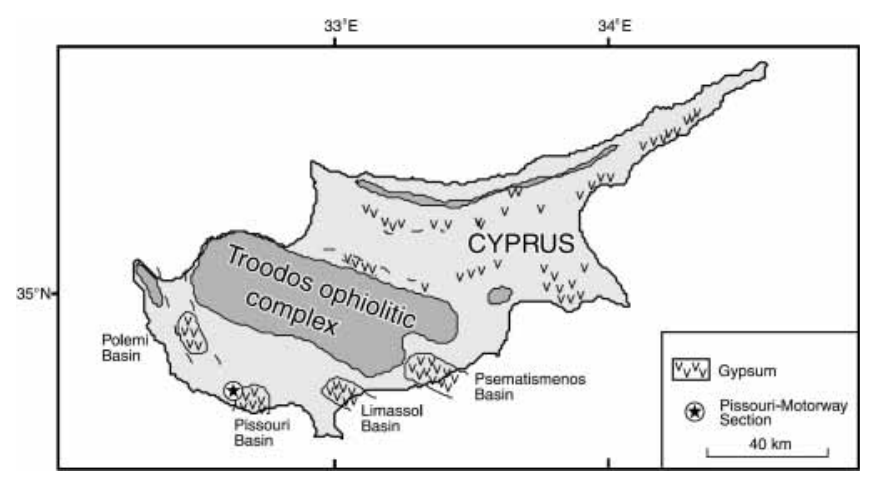

Fig. 1. Location of the Pissouri section on Cyprus (Krijgsman et al. 2002).

frequency and amount toward the evaporitic stage of the salinity crisis (Krijgsman et al., 2002). For the earliest Pliocene of the Pissouri Basin a depth of at least $300 \mathrm{~m}$ has been estimated, with a deepening trend (Rouchy et al., 2001).

Studies on Neogene and Pleistocene sediments from the Gulf of Suez and the Red Sea and on drilling sites of the Ocean Drilling Program (ODP sites 658-661) resulted in the assumption that northeastern Africa had a relatively humid climate during the late Messinian and was strongly influenced by high monsoonal activity (Griffin, 1999). This precipitation-rich period peaked into the late Messinian during the lowstand in the Mediterranean Basin and led to increased sedimentation rates caused by a higher clastic input by rivers (Griffin, 1999). The Tortonian was characterized by a relatively arid eastern Mediterranean (Griffin, 1999).

\section{MATERIAL AND METHODS}

\section{Material}

The upper Miocene marine succession of the Pissouri Basin in Cyprus consists of an alternation of indurated carbonate-rich and less indurated marlier beds and shows a distinct cyclicity (Krijgsman et al., 2002; Kouwenhoven et al., 2006). The softer marly beds of the Pissouri section can be correlated with contemporaneous sapropelic layers throughout the Mediterranean (Kouwenhoven et al., 2006).

The record here from Cyprus comprises the complete marine succession of the Pissouri Basin before, during and after the Messinian salinity crisis. The calcareous dinoflagellate data of this paper are derived from two land sections in the Pissouri Basin (Fig. 1), the Pissouri motorway section (40 samples) (Krijgsman et al., 2002) and the Pissouri village section (1 sample) (Orszag-Sperber et al., 1989, 2000; Rouchy et al., 2001). The Pissouri motorway section is located along the LimassolPaphos motorway (Krijgsman et al., 2002) about $100 \mathrm{~m}$ west of the Pissouri village section, which is exposed at the eastern entry of Pissouri (Rouchy et al., 2001). The samples comprise the interval between the upper Tortonian at c. $7.6 \mathrm{Ma}$ (cycle VII) up to the base of the massive lower gypsum deposits at $5.98 \mathrm{Ma}$ (cycle 1) and the first centimetres of the basal Pliocene, belonging to the Miocene-Pliocene 1 Biozone of Cita (1975) (MPL1), deposited under deep-marine conditions (Rouchy et al., 2001) (Fig. 2). The upper Messinian evaporitic and post-evaporitic interval (5.96-5.32 Ma) was not considered due to its essentially non-marine character (e.g. Castradori, 1998; Rouchy et al., 2001).

Except for the uppermost two cycles of the Tortonian, the upper Tortonian and lower Messinian cycles are thinner (around $2.6 \mathrm{~cm} \mathrm{ka}^{-1}$ ) than those from the upper Messinian (around $5 \mathrm{~cm} \mathrm{ka}^{-1}$ ) (Kouwenhoven et al., 2006) (Fig. 2). Consequently, from cycle 18 upwards the sedimentation rates are on average twice as high as those in the cycles below. A detailed description of the Pissouri motorway section is given in Krijgsman et al. (2002) and Kouwenhoven et al. (2006).

\section{Methods}

Samples consisting of $0.5 \mathrm{~g}$ dried sediment were disaggregated in $100 \mathrm{ml} 0.6 \%$ Soda solution. For samples with elevated organic matter contents (e.g. from sapropels), disaggregating and organic matter oxidation were combined in a $10-15 \% \quad \mathrm{H}_{2} \mathrm{O}_{2}$ solution. To speed up the oxidation process samples were heated briefly to $50^{\circ} \mathrm{C}$. Samples failing to disaggregate with these procedures were treated with repeated freezing and thawing in saturated sodium sulphate solution. After disaggregating, the suspensions were treated with ultrasound for less than 1 minute to further separate the particles. The $20-75 \mu \mathrm{m}$ fraction was isolated from the sample by washing with tap water over $75 \mu \mathrm{m}$ and $20 \mu \mathrm{m}$ sieves. Randomly selected pilot samples of the $<20 \mu \mathrm{m}$ and $>75 \mu \mathrm{m}$ fractions appeared to contain no calcareous dinoflagellate cysts. To avoid carbonate dissolution, care was taken to perform all procedures in a slightly alkaline environment by adding a few drops of ammonia if necessary.

The $20-75 \mu \mathrm{m}$ fraction was washed in a scaled $20 \mathrm{ml}$ test tube with lid. To reduce the surface tension and avoid contamination by fungi a few drops of ammonia and ethanol were added (Vink et al., 2000). After a few hours settling, the water was removed with a pipette to a sample volume of $12 \mathrm{ml}$ or $15 \mathrm{ml}$, depending on the amount of material. For quantitative scanning electron microscopic (SEM) analyses, a round cover glass (13 $\mathrm{mm} \mathrm{Ø)} \mathrm{was}$ applied to the tab using a double-sided adhesive lead-tab. Subsequently, a $50 \mu \mathrm{l}$ sub-sample was applied to the SEM stub. This sub-sample was taken at a depth of $1 \mathrm{~cm}$ below the surface of the thoroughly homogenized $12 \mathrm{ml}$ or $15 \mathrm{ml}$ sample using an Eppendorf micropipette. To get a better dispersion of the particles on the cover glass, surface tension was reduced by adding a small drop of ethanol. The solvents were evaporated by heating the stub to nearly $100^{\circ} \mathrm{C}$. The stubs were sputtered with gold prior to SEM examination. SEM conditions were 15$20 \mathrm{kV}$, working distance $12-15 \mathrm{~mm}$. Cysts were counted under the SEM, if necessary, multiple SEM stubs were analysed to reach a statistical relevant outcome. However, cyst concentrations were extremely low for the upper Messinian samples (see Appendix B). The number of cysts per milligram of dry sediment counted on the SEM stubs was calculated as:

$$
\text { cysts } / \mathrm{mg}=C \times S_{\mathrm{t}} /\left(S_{\mathrm{q}} \times N \times M\right),
$$

where $C$ is the number of counted cysts, $S_{\mathrm{t}}$ represents the total sample volume in $\mathrm{ml}(10-15), S_{\mathrm{q}}$ represents the sub-sample volume applied to the stub in $\mathrm{ml}(0.05$ or 0.10$), N$ is the number of counted stubs and $M$ represents the dry weight of the examined sediment. Diversity was calculated as follows: 


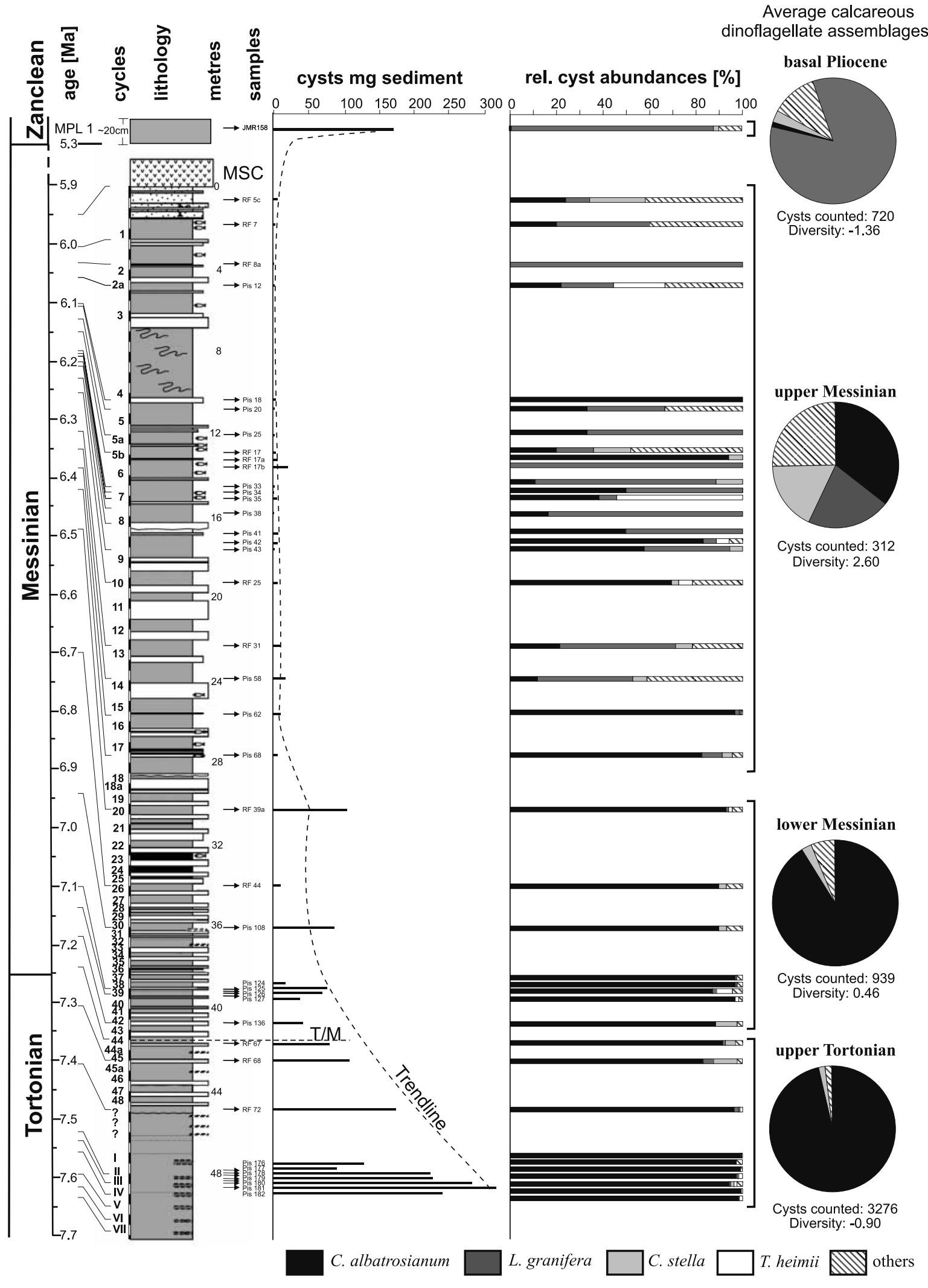




$$
H=\sum_{i=1}^{n}\left(p_{i} \ln p_{i}\right)
$$

Where $H$ is the Shannon-Weaver Diversity Index, which increases with increasing heterogeneity of the sample. $P_{i}$ is the relative abundance of individuals in the $i$ th species, $n$ is the total number of species in the community (richness), and $\ln$ is the natural logarithm.

Additionally, selected samples were analysed by polarized light microscopy with a gypsum plate (Janofske, 1996) to study the crystallographic orientation of the wall crystals. Especially for species with strong morphological similarities, e.g. C. levantinum and $P$. tuberosa, or morphological variations due to diagenetic overprint such as for L. granifera, the light optical investigations were used for species differentiation. Within a precession cycle the carbonate beds and marly intervals represent opposite environmental conditions. To enable analysis of the longer-term environmental changes and to circumvent problems with the often unproductive carbonate beds and ensure sample intercomparability, samples were analysed from the marly beds only. For taxonomic information of the examined species see Appendix A.

\section{Repository}

The studied material is deposited in the collection of the Division of Historical Geology and Palaeontology, Department of Geosciences, University of Bremen, Germany.

\section{RESULTS}

Within the investigated interval 13, generally well-preserved calcareous dinoflagellate species have been identified with strongly varying relative and absolute abundances through time (Fig. 2; App. B). Cyst concentrations (cysts $\mathrm{mg}^{-1}$ of dry sediment) vary strongly (Fig. 2). Highest concentrations were recorded in the upper Tortonian samples (79-317 cysts $\mathrm{mg}^{-1}$ ), while the lowest cyst concentrations are found in the upper Messinian samples $\left(<21\right.$ cysts $\left.\mathrm{mg}^{-1}\right)$.

The diversity of the recorded dinoflagellate assemblages fluctuates between very low diversities in the upper Tortonian interval (on average: $H=-0.90$ ) and moderate to low diversities in the lower Messinian (on average: $H=0.46$ ) (Fig. 2; App. B). The dominating species of both time intervals is $C$. albatrosianum with relative abundances $>83 \%$, reaching maximum values of $100 \%$ in the upper Tortonian samples (Fig. 2). On average, $C$. albatrosianum distinctly dominates the upper Tortonian and lower Messinian assemblages, with $96 \%$ and $92 \%$ respectively (Fig. 2).

The upper Messinian is marked by strongly varying relative cyst abundances and very low cyst concentrations (0.2-21 cysts $\left.\mathrm{mg}^{-1}\right)$. As a result of this high variability, the average assemblage of this interval is much more diverse $(H=2.60)$ and, depending on the sample, dominated by $C$. albatrosianum, $L$. granifera or Caracomia stella (Fig. 2; App. B). Compared to the upper Tortonian/lower Messinian, C. albatrosianum loses its distinct supremacy and becomes rarer, with an average relative abundance of $34 \%$ in this interval (Fig. 2). L. granifera and $C$. stella clearly increase and temporally dominate the associations but with opposite trends (Fig. 2). T. heimii, Pirumella parva, Calciodinellum operosum and Melodomuncula berlinensisbecome more important (Fig. 2).

During the basal Pliocene the dominating species of the Tortonian/Messinian period are replaced by L. granifera with an $87 \%$ relative abundance (Fig. 2). This assemblage is marked by a relatively high cyst concentration $\left(172\right.$ cysts $\left.\mathrm{mg}^{-1}\right)$. The diversity is relatively low again $(H=-1.36)$, even though the number of species (8) is comparatively high (Fig. 2). Species with slightly increased relative abundances are Rhabdothorax spp. $(5 \%)$ and $C$. stella (3\%). In addition C. elongatum occurs for the first time ( $2 \%$ of the assemblage) (Fig. 2).

Light microscopic observations of the sibling species $C$. levantinum and $P$. tuberosa showed that only the latter was present.

\section{DISCUSSION}

On the basis of calcareous dinoflagellates, the lithology and stratigraphy, four stratigraphic intervals were distinguished, reflecting environmental conditions caused by the Messinian salinity crisis: (1) upper Tortonian interval, (2) lower Messinian interval, (3) upper Messinian interval and (4) basal Pliocene (Fig. 2).

The upper Tortonian is more or less monospecific and strongly dominated by $C$. albatrosianum, similar to the open tropical to subtropical Atlantic Ocean today (Vink, 2004). C. albatrosianum has been suggested to be a typical thermoclinedwelling species with a clear connection to warm, oligotrophic waters (Janofske \& Karwath, 2000; Wendler et al., 2002a, b; Vink, 2004). It also occurs in the eutrophic upwelling regions of the Arabian Sea (Wendler et al., 2002a, b) and the equatorial and Benguela upwelling areas (Vink, 2004) but always with lower abundances than in the open ocean (Wendler et al., 2002a, b; Vink et al., 2003; Vink, 2004).

One of the most striking features of the upper Tortonian interval is the extremely low diversity caused by the distinct dominance of C. albatrosianum (Fig. 2). Calcareous dinoflagellates which tolerate a wide range of environmental conditions have their highest diversity in coastal and more neritic regions (Karwath et al., 2000; Vink et al., 2003; Vink, 2004). Low diversities and dominance of a single species, such as during the Tortonian, indicates relatively stable oceanic conditions (Hildebrand-Habel \& Willems, 1997; Kohring, 1997; Meier \& Willems, 2003; Kohring et al., 2005). This is in contrast to planktic foraminifera and coccolithophora, where low diversities are typical characteristics of unstable, restricted environmental conditions (Kouwenhoven, 2000; Wade \& Bown, 2005; Kouwenhoven et al., 2006).

Fig. 2. Lithology (after Krijgsman et al., 2002), age and cyst abundances (cysts $\mathrm{mg}^{-1}$ sediment) of the analysed samples and relative abundances of C. albatrosianum, L. granifera, C. stella, T. heimii and other cysts in the analysed samples against time. Lithology according to Krijgsman et al. (2002). White levels correspond to more indurated beds, black levels to organic-rich layers (sapropels) and grey levels to softer blue-greyish and laminated marls; dotted levels represent the transitional interval to the evaporites composed of stromatolithic limestones; the ' $\mathrm{v}$ '-signed levels symbolize gypsum. Additionally, average calcareous dinoflagellate assemblages in relative abundances and average diversity during the upper Tortonian, lower Messinian, upper Messinian and the basal Pliocene are shown. 
The lower Messinian interval has much less cysts $\mathrm{mg}^{-1}$ of dry sediment than the upper Tortonian one (Fig. 2). The assemblages are almost similar with only a slight decrease of $C$. albatrosianum and conversely a slightly increased diversity within the lower Messinian samples. These changes are caused mainly by increased relative abundances of $L$. granifera and $C$. stella. In the case of $L$. granifera this indicates a progressively riverine influence (Vink et al., 2000; Wendler et al., 2002b, c; Vink, 2004) caused by the progressive separation of the Mediterranean Basin from the Atlantic Ocean. C. stella is, as yet, known only from warmer environments from low and middle latitudes of Miocene/Pliocene age (e.g. Fütterer, 1977; Kohring, 1993a, b, 1997; Keupp \& Kohring, 1999; Streng et al., 2002; Hildebrand-Habel \& Streng, 2003) and from surface samples of the South Atlantic Ocean (Streng et al., 2002). Higher relative abundances of $C$. stella are associated with more shelfward environments (Keupp \& Kohring, 1999; this work) but with a distribution pattern opposite to L. granifera (Fig. 2). Furthermore, higher concentrations of $C$. stella in the Mediterranean upper Miocene/Pliocene (Keupp \& Kohring, 1993, 1999; Kohring, 1993b, 1997; this work) occur together with C. albatrosianum, representatives of the edgarii-group and P. tuberosa, implying similar environmental preferences (Table 1, Fig. 2). Hence, higher abundances of $C$. stella are probably indicative of oligotrophic, coastal warm waters with normal or slightly increased salinities.

Thus, the modifications of the lower Messinian interval possibly already reflect the beginning of more unstable and restricted conditions caused by the Messinian salinity crisis. Importantly, this first notable shift in calcareous dinoflagellate assemblages already occurs shortly before the TortonianMessinian boundary at 7.3 Ma (Fig. 2; sample RF 66) and pre-dates the disappearance of a group of open-marine, deepwater benthic foraminifera taxa at $7.167 \mathrm{Ma}$ in the Pissouri Basin (Kouwenhoven et al., 2006).

The third, upper Messinian, interval is much more diverse $(H=0.58-4.61)$ but possesses only few cysts. The dinoflagellate assemblages reveal striking variations in species abundances (Fig. 2) which are interpreted as reflecting fluctuating salinities, nutrients and temperatures towards the evaporitic stage. All samples show an inverse relationship between $L$. granifera on the one hand and $C$. stella and to an even larger extent $C$. albatrosianum on the other. Abundance peaks of L. granifera, together with a decrease in $C$. albatrosianum and $C$. stella, are likely the response to enhanced continental runoff, resulting in nutrient-enriched surface waters with reduced salinities. High abundances of $C$. albatrosianum can be interpreted as a temporary re-establishment of normal marine oligotrophic conditions. In contrast to this, the sporadic occurrence of the more neritic Bicarinellum tricarinelloides, Melodomuncula berlinensis, Pirumella parva and Rhabdothorax spp. indicate temporary shallowing of the basin. On average the upper Messinian assemblage is much more diverse $(H=2.6)$ and reflects very unstable, more neritic conditions with varying fluvial input. Additionally, frequent occurrence of ascidian sclerites emphasizes the more neritic character of this interval (Fütterer, 1977).

The basal Pliocene assemblage reflects the restoration of normal marine conditions just after the replenishment of the Mediterranean Basin (Spezzaferri et al., 1998; Rouchy et al.,

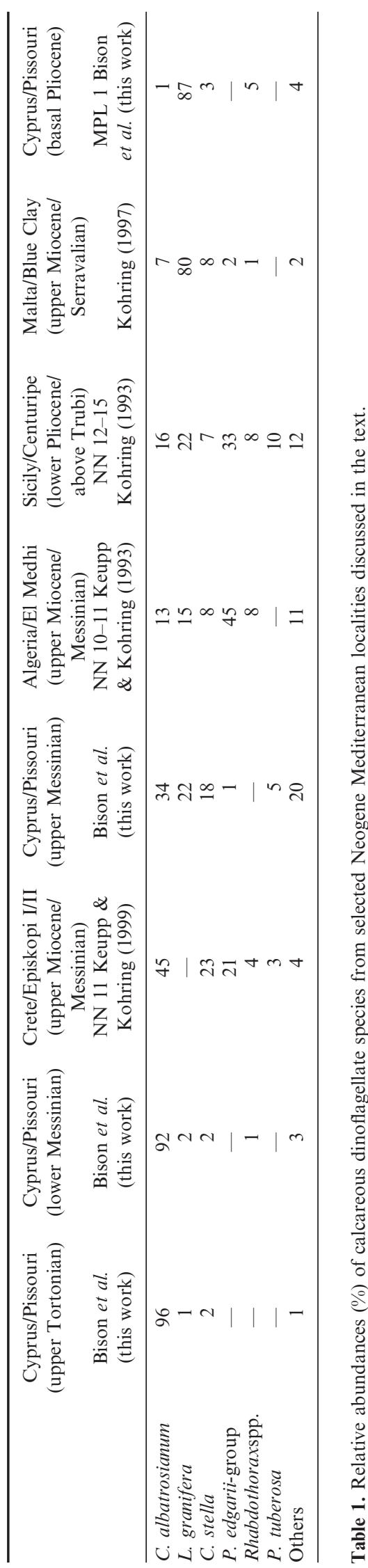


2001). However, a strong change in the association, compared with the Miocene assemblages, took place: $L$. granifera clearly dominates the assemblage and obviously replaced C. albatrosianum. It is hypothesized that a low salinity, high nutrient layer of fresh water must have spread out over the dense, saline waters. Rouchy et al. (2001) and Iaccarino et al. (1999) also observed a continued and significant fresh-water input in the Mediterranean Basin, which probably affected particularly proximal land areas such as the Pissouri Basin in the eastern Mediterranean (Iaccarino et al., 1999; Rouchy et al., 2001). These observations support the hypothesis that simultaneous to the salinity crisis, the Mediterranean climate changed from a more arid Tortonian to a humid late Messinian and basal Pliocene one (Diester-Haass et al., 1998; Fauquette et al., 1998), marked by high monsoonal activity (Griffin, 1999). Such intensified monsoonal precipitation also occurs during orbital precession minima which are, in turn, associated with strong Northern Hemisphere $(\mathrm{NH})$ summer insolation, resulting in increased discharge from the Nile (e.g. Rossignol-Strick, 1985; Hilgen, 1991; Diester-Haass et al., 1998). Although Mediterranean sapropels have been formed during precession minima (Wehausen \& Brumsack, 1998; Lange et al., 1999; Meier et al., 2004), precession minima at the basal Pliocene (RossignolStrick, 1985; Hilgen, 1991; Castradori, 1998; Steenbrink et al., 2006; Van der Laan et al., 2006) did not lead to sapropel formation in the Pissouri Basin.

\section{Comparison with other Neogene Mediterranean assemblages}

The species spectrum of calcareous dinoflagellates from the Pissouri section agrees well with that reported by most other Neogene studies from the Mediterranean so far (Keupp \& Kohring, 1993, 1999; Kohring, 1993, 1997; Table 1). Only some rare species, such as Cervisiella saxea and Calcipterellum colomi, could not be found in the Pissouri samples. One exception is Orthopithonella sicelis, which is known only from a poorly preserved lower Pliocene section on Sicily, where it dominates $(26 \%)$ the calcareous dinoflagellate assemblage (Kohring, 1993; Table 1, included in the edgarii-group). In the authors' opinion this basal Pliocene assemblage from Sicily reflects a more neritic environment, with $O$. sicelis as the dominating species and abundant $P$. parva. In the material $O$. sicelis could not be found, whereas P. parva is scarce (Fig. 2). An obvious explanation is that the basal Pliocene of the Pissouri Basin represents a deeper-marine environment (Rouchy et al., 2001) unsuitable for these taxa.

However, a comparison of the Pliocene dinoflagellate assemblage from Sicily (Kohring, 1993) and Messinian assemblages from Algeria (Keupp \& Kohring, 1993) with this upper Messinian assemblage shows more agreement in relative abundances and the species spectrum (Table 1). All three assemblages are relatively highly diverse and share most major members $(L$. granifera, C. albatrosianum, C. stella); however, there are deviations in relative abundances and lower contributions of $C$. albatrosianum and C. stella in the Algerian and Sicilian assemblages (Table1). The striking difference between the upper Miocene assemblage of the Pissouri section and those of the Algerian and Sicilian ones is the high abundance of representatives of the edgarii-group in the latter sections (Table 1), which gives them a stronger neritic character. Furthermore, the Sicilian assemblage is characterized by a slightly higher amount $(10 \%)$ of O. tuberosa (now Pirumella tuberosa), reflecting elevated salinity and more oligotrophic conditions (Vink, 2004). Therefore, the dilution and eutrophication via fluviatile input might have been less significant.

A relatively shallow warm-water environment is proposed, with mesotrophic and mesohaline conditions for the late Miocene Algerian and basal Pliocene Sicilian sedimentation areas. Although Kohring (1993) and Keupp \& Kohring (1993) also assumed warm-water conditions and revealed the nearshore character of the edgarii-group, a concluding interpretation of the environment is missing. Abundance variations of $C$. albatrosianum and L. granifera (formerly Sphaerodinella albatrosiana and Orthopithonella granifera, respectively) are seen merely as fluctuating Atlantic influences. These variations are interpreted as fluctuating terrigenous runoff and associated salinity and nutrient variations.

Regardless of the different stratigraphical and palaeogeographical positions, the basal Pliocene assemblage and the upper Miocene (Serravallian) assemblage of Kohring (1997) from Malta (Blue Clay Formation) agree well (Table 1). Both assemblages are more or less monospecific, with a clear dominance of L. granifera ( $87 \%$ and $80 \%$ respectively), reflecting a strong fluviatile influence.

Keupp \& Kohring (1999) described a calcareous dinoflagellate assemblage from the upper Miocene of Crete (Episkopi) (Table 1) which differs from the aforementioned associations by the absence of L. granifera and elevated amounts of C. albatrosianum. Again, due to its interpretation as a typical pelagic open marine species (Kohring, 1993, 1997), Keupp \& Kohring (1999) interpreted the absence of L. granifera as a decreasing Atlantic influence. The absence of L. granifera is further attributed to missing fluviatile influence.

These results agree well with other microfossil studies of the Pissouri Basin (Rouchy et al., 2001; Krijgsman et al., 2002; Kouwenhoven et al., 2006). Only the calcareous dinoflagellates reported by Kouwenhoven et al. (2006) differ significantly from the current data; this relates to the use of different methodologies and taxonomic concepts.

The interpretation of a warm, oligotrophic environment for the upper Tortonian interval correlates well with the distribution pattern of coccoliths and planktic foraminifera (Kouwenhoven et al., 2006). These authors infer a transition from a cool-water, high-productivity environment (abundance maximum of Coccolithus pelagicus) to higher sea surface temperatures (SST) and oligotrophic conditions just below the lowermost sample at 7.5 Ma. This shift is also apparent from the decrease in the cold-water-indicating planktic foraminifera (Neogloboquadrinids and Globorotalia spp.) and an increase in the subtropical and oligotrophic Globigerinoides spp. (Kouwenhoven et al., 2006).

\section{Pissouri Basin associations versus recent Mediterranean assemblages}

The calcareous dinoflagellate assemblages from the Pissouri Basin are very unlike those of the recent Mediterranean Sea. Although most of the main upper Miocene to lower Pliocene calcareous dinoflagellate species are extant, some species of the modern Mediterranean are missing in the record from this study 


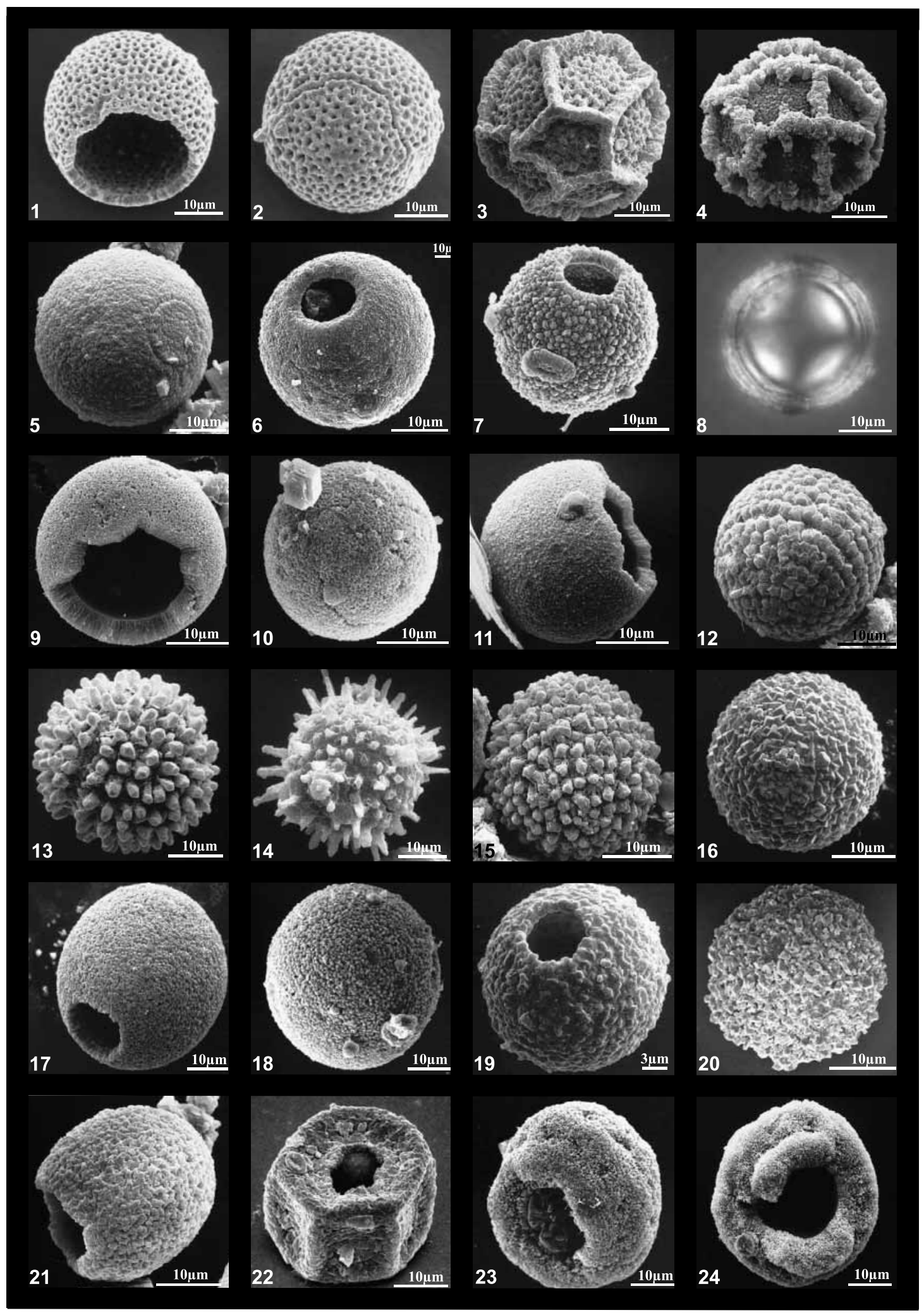


and vice versa. The most relevant species in this context are $C$. levantinum and $P$. parva. C. levantinum today dominates the western Mediterranean associations but distinctly decreases eastwards (Meier \& Willems, 2003). Currently it is unknown when $C$. levantinum started its extension into the eastern Mediterranean Basin. P. parva, a representative of the edgariigroup, is lacking in the modern Mediterranean. This species disappeared possibly somewhere during the late Pliocene, possibly in relation to the onset of the Northern Hemisphere glaciations (Streng et al., 2004). P. parva has been suggested to prefer nearshore environments and warm waters (HildebrandHabel \& Willems, 2000; Hildebrand-Habel \& Streng, 2003).

The dominance of $C$. albatrosianum in the upper Tortonian to lower Messinian assemblages has no equivalent in the modern Mediterranean. Today this species accounts for less than $5 \%$ of the Mediterranean associations (Meier \& Willems, 2003), similar to its abundance in the Pliocene record here. It is proposed that conditions similar to those in modern oceans, with high amounts of C. albatrosianum (Wendler et al., 2002a; Tanimura \& Shimada, 2004; Vink, 2004), prevailed in the Mediterranean during the late Tortonian and early Messinian.

C. elongatum, a common species in the eastern Mediterranean today, and which occurs for the first time in the basal Pliocene sample, might be seen as an Atlantic newcomer.

T. heimii is the most abundant calcareous dinoflagellate species in the present-day Mediterranean Sea (e.g. Zonneveld et al., 2001; Meier \& Willems, 2003). This species, which can be traced back to the K/T boundary (Hildebrand-Habel et al., 1999), occurs in the material only sporadically and with very low relative and absolute abundances $\left(<2\right.$ cysts $\left.\mathrm{mg}^{-1}\right)$. The only exceptions are in two of the upper Messinian samples (Fig. 2) where this species accounts for $22 \%$ and $54 \%$ of the assemblage. However, in total, this species remains rare over the Messinian salinity crisis and after the restoration of marine conditions with the beginning of the Pliocene. Until now it remains unclear why, and when, T. heimii started to dominate the Mediterranean calcareous dinoflagellate assemblages.

L. granifera and C. stella, which increase in proximity to the Messinian salinity crisis, are either very scarce or not present $(C$. stella) in the modern Mediterranean (Meier \& Willems, 2003).

Only one specimen of L. granifera was reported from a survey of surface samples taken throughout the Mediterranean by
Meier \& Willems (2003). However, this species is abundant in the S1 sapropel (c. $8-30 \%$ of the assemblages) (Meier et al., 2004), an environment which is therefore closer to the basal Pliocene environment. The other species linked to the S1 sapropel, C. levantinum, is not present in the samples. Compared to the present Mediterranean, which is characterized by oligotrophic, high saline water masses with strong east-west gradients (Meier et al., 2004), the Mediterranean during S1 deposition was marked by enhanced fresh-water discharge and consequently increased nutrient concentration (Meier et al., 2004). A similar situation, but far much severe, is proposed to have occurred during the basal Pliocene in the eastern Mediterranean, when huge amounts of fresh water spread out over the re-establishing Mediterranean (e.g. Diester-Haass et al., 1998; Rouchy et al., 2001). The species that apparently benefits most from this configuration in both settings is L. granifera. Interestingly, this did not lead to sapropel formation in the earliest Pliocene, suggesting sufficient ventilation of the deeper water masses.

The low relative abundance of $C$. albatrosianum mentioned above, a feature of this basal Pliocene assemblage, is in common with the modern Mediterranean ones. Furthermore, L. urania and $C$. elongatum, which are common in the eastern Mediterranean today, peak (L. urania) or appear for the first time ( $C$. elongatum) in the Pliocene material.

L. urania and $C$. elongatum have a strong affinity with oligotrophic waters of elevated salinities, such as in the modern eastern Mediterranean, where these species form large parts of the calcareous dinoflagellate assemblages (Meier et al., 2004). Today L. urania is restricted almost entirely to the high saline (c. $39 \mathrm{psu}$ ) and oligotrophic eastern Mediterranean Sea and only a few specimens have been recorded from the Tyrrhenian Sea (Meier et al., 2002, 2004; Meier \& Willems, 2003). Even though L. urania and C. elongatum are present within the basal Pliocene samples they remain scarce. L. urania is restricted to the eastern Mediterranean today, it has also been reported from the Miocene Indian Ocean (Streng et al., 2004), but not from the Atlantic. This gives the species a Tethyan rather than an Atlantic signature. Therefore, it is suggested, in agreement with Meier \& Willems (2003), that some specimens of L. urania survived the salinity crisis within the Mediterranean. It is unclear when $L$. urania established its dominant position in the eastern Mediterranean.

Explanation of Plate 1.

Scanning electron (SEM) images and one light microscope image. figs 1-2. Calciodinellum albatrosianum (sample PIS182, upper Tortonian, apical view): 1, open cyst with polygonal archaeopyle; 2, closed cyst with polygonal delineated operculum. figs 3-4. Calciodinellum operosum (sample RF17a, upper Messinian): 3, paratabulated cyst with well-developed crystal ridges and large pores; 4, lateral view, closed cyst with blocky crystallite ridges and reduced pores. figs 5-8. Leonella granifera (sample JMR158): 5, basal Pliocene, side apical view, SEM image, spherical cyst with round operculum; 6, sample RF17a, upper Messinian, side apical view, SEM image, cyst with open archaeopyle; 7, basal Pliocene, side view, SEM image, cysts with open archaeopyle and coarser surface crystallites. 8, light optical view under crossed nicols. figs 9-11. Caracomia stella Streng et al., 2002: 9, sample RF17a, upper Messinian, apical view, open cyst with large polygonal archaeopyle; 10, sample JMR158, basal Pliocene, side apical view of closed cyst, with delineated archaeopyle suture; 11, sample RF17a, upper Messinian, side view of open cyst. fig. 12. Lebessphaera urania (sample PIS136, upper Tortonian), lateral view of closed cyst, operculum suture visible in the upper part. figs 13-15. Rhabdothorax spp. (upper Messinian): 13, sample PIS126, spherical closed cyst with shorter blocky spines; 14, sample PIS108, closed cyst with long spines; 15, sample PIS126, spherical cyst with reduced blocky spines. fig. 16. Pernambugia tuberose (sample RF17a, upper Messinian), closed spherical cyst with pyramid-like cyst surface crystals. figs 17-18. Pirumella parva (sample PIS68, upper Messinian): 17, side apical view, elongated cyst with small round archaeopyle; 18, spherical closed cyst, no operculum suture visible. fig. 19. Thoracosphaera heimii (sample PIS41, upper Messinian), spherical cyst with small round archaeopyle, irregular surface crystals. fig. 20. Pirumella loeblichii (sample PIS180, upper Tortonian), spherical cyst with irregularly arranged surface crystals. fig. 21. Calciodinellum elongatum (sample JMR158, basal Pliocene), elongated cyst with open paratabulated archaeopyle. fig. 22. Melodomuncula berlinensis (sample RF17a, upper Messinian), lateral apical view of open cyst. figs 23-24. Bicarinellum tricarinelloides (sample RF17a, upper Messinian): 23, side apical view of open cyst; 24, same cyst, apical view. 


\section{CONCLUSIONS}

The impact of the Messinian salinity crisis on Mediterranean calcareous dinoflagellate assemblages was analysed from the Pissouri Basin on Cyprus. Time slices before, during and after the salinity crisis were investigated. The main objective of this paper was to investigate longer-term palaeoenvironmental changes in relation to the Messinian salinity crisis in the eastern Mediterranean based on calcareous dinoflagellates. The dominance of $C$. albatrosianum and its high absolute and relative abundance during the late Tortonian and early Messinian is unlike modern Mediterranean Sea associations. It is most similar to the modern tropical Atlantic (Vink et al., 2002). Changing environmental conditions caused by the separation of the Mediterranean Sea from the Atlantic Ocean, superimposed by shortterm (precession-controlled) variability, led to the replacement of C. albatrosianum-dominated assemblages by L. graniferadominated ones after the salinity crisis. At the same time the species diversity changed from low diverse, almost monospecific associations during the late Tortonian and early Messinian, through relatively highly diverse associations during the late Messinian, to low diversity ones again during the basal Pliocene. With the re-filling of the Mediterranean Basin, just after the Miocene/Pliocene boundary, the Atlantic element C. elongatum occurs for the first time and contributes to a more modern character of the Pliocene associations. The basal Pliocene calcareous dinoflagellate assemblage most closely resembles those of the Holocene S1 sapropel but still differs from the present Mediterranean ones. The final changes to current Mediterranean calcareous dinoflagellate associations must have taken place after the disappearance of the more or less monospecific earliest Pliocene association. Finally, it can be said that the Messinian salinity crisis did not lead to a permanent removal of oceanic calcareous dinoflagellate taxa from the Pissouri Basin. Most of the dinoflagellate cyst species of this period are still present in the modern Mediterranean and they can be interpreted as re-immigrants to the Mediterranean from the Atlantic. The exception is L. urania, which must have survived the salinity crisis in the Mediterranean.

\section{ACKNOWLEDGEMENTS}

The authors thank Jacob Nsiah (Bremen University) for preparing the samples and Hartmut Mai (Bremen University) for assistance and advice during the SEM analysis. Wout Krijgsman (Utrecht University) is thanked for making available the samples and Jean-Marie Rouchy and Rachel Flecker for providing additional sample material. Special thanks go to Erik Snel, Erwin van der Laan and Tanja Kouwenhoven, (Utrecht University) for their constant assistance with the procurement of the samples. We also thank all members of the working group of Historical Geology and Palaeontology of Bremen University for their general assistance and openness to discussion. The authors are particularly grateful to the two reviewers Sebastian Meier and Helmut Keupp for valuable suggestions and criticisms that helped to improve the manuscript. The editor, John Gregory, is thanked for his critical review of the manuscript. Financial support by the German Research Foundation is gratefully acknowledged. Thanks also go to Jean-Marie Rouchy and Rachel Flecker for providing additional sample material.
APPENDIX A: Annotated listing of calcareous dinoflagellate taxa found in the investigated material

Division Dinoflagellata (Bütschli, 1885) Fensome et al., 1993

Subdivision Dinokaryota Fensome et al., 1993

Class Dinophyceae Pascher, 1914

Subclass Peridiniphycidae Fensome et al., 1993

Order Peridiniales Haeckel, 1894

Suborder Peridiniineae Autonym

Family Peridiniaceae Ehrenberg, 1831

Subfamily Calciodinelloideae Fensome et al., 1993

Bicarinellum tricarinelloides Versteegh, 1993 (Pl. 1, figs 23, 24)

Calciodinellum albatrosianum (Kamptner, 1963) Janofske \& Karwath, 2000 (P1. 1, figs 1, 2)

Calciodinellum elongatum (Hildebrand-Habel et al., 1999) Meier et al., 2002 (P1. 1, fig. 21)

Calciodinellum operosum Deflandre, 1947 (Pl. 1, figs 3, 4)

Caracomia stella (Gilbert \& Clark, 1983) Streng et al., 2002 (Pl. 1, figs 9-11)

Lebessphaera urania Meier et al., 2002 (Pl. 1, fig. 12)

Melodomuncula berlinensis Versteegh, 1993 (P1. 1, fig. 22)

Pernambugia tuberosa (Janofske \& Karwath, 2000) Hildebrand-

Habel et al., 1999 (Pl. 1, fig. 16)

Pirumella parva (Bolli, 1974) Lentin \& Williams, 1993 (Pl. 1, fig 17-18)

Pirumella loeblichii (Bolli, 1974) Lentin \& Williams, 1993 (Pl. 1, fig. 20)

Rhabdothorax spp. (Kamptner, 1937) Kamptner, 1958 (Pl. 1, figs 13-15)

Order Thoracosphaerales Tangen in Tangen et al., 1982

Family Thoracosphaeraceae Schiller, 1930 emend. Tangen in Tangen et al., 1982

Thoracosphaera heimii (Lohmann, 1920) Kamptner, 1944 (P1. 1, fig. 19)

Leonella granifera (Fütterer, 1977) Janofske \& Karwath, 2000 (P1. 1, figs 5-8)

According to the new phylogenetic ideas of Gottschling et al. (2005) and the close relationship of Leonella and Thoracpsphaera, L. granifera is grouped under Thoracospherales rather than under Calciodinelloids, as previously. The light optical appearance of the cysts is identical to that of typical L. granifera. However, upon SEM analysis it appears that most of the $L$. granifera cysts differ from the type in the absence of pores in the outer cyst surface and by a characteristic wall surface with epitaxially grown crystals. Since the whole spectrum of intermediate forms is also observed, the observed morphological variation is interpreted as a slight diagenetic overprint. This morphological variation of $L$. granifera was also observed in other Neogene Mediterranean samples (e.g. Keupp \& Kohring, 1993; Kohring, 1993).

\section{APPENDIX B}

Table B1 shows the count data and calculated diversity data for all analysed samples.

Manuscript received 26 July 2005

Manuscript accepted 23 January 2007 
Calcareous dinoflagellates of the Messinian salinity crisis

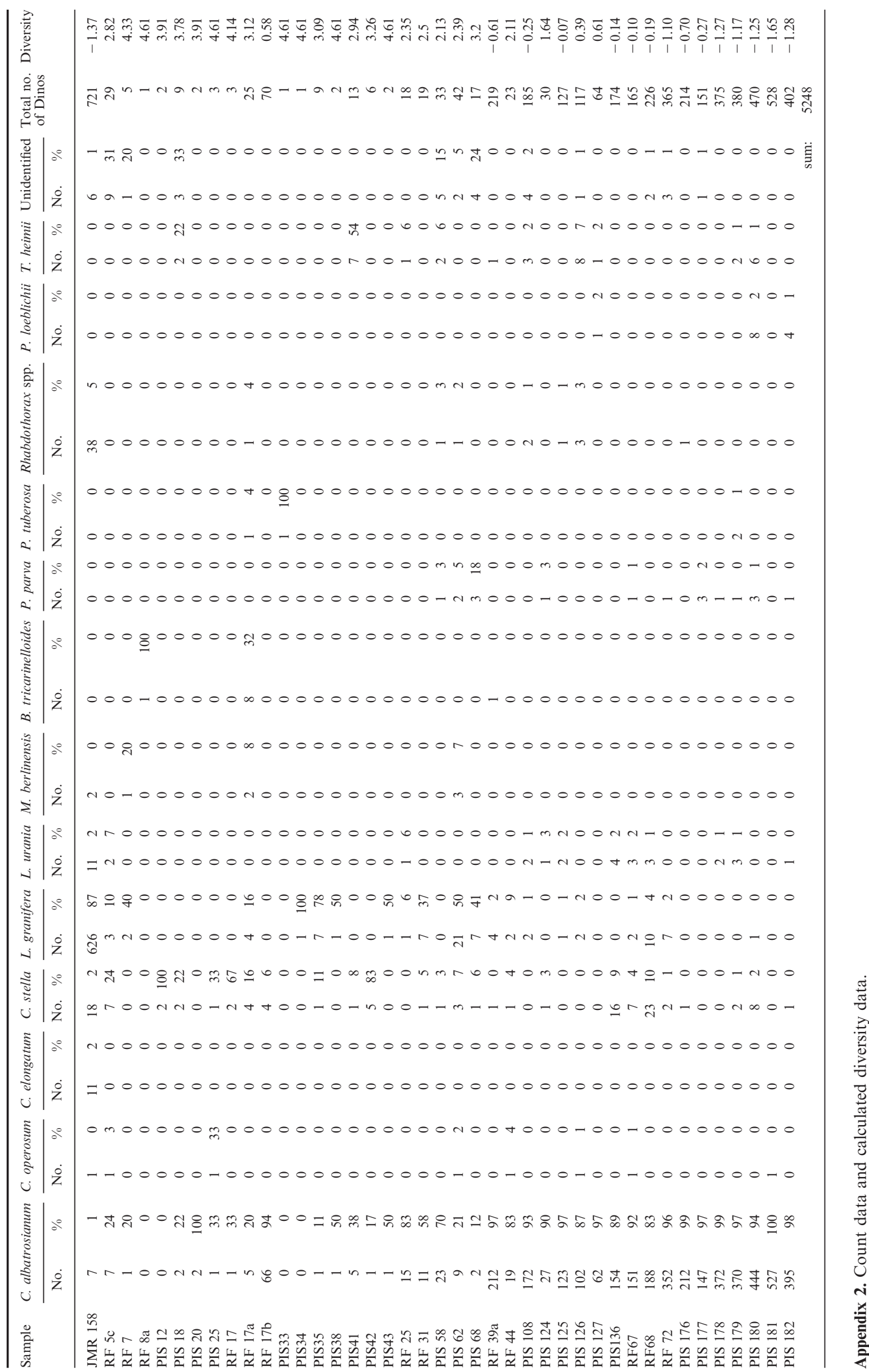




\section{REFERENCES}

Bianchi, C.N. \& Morri, C. 2000. Marine biodiversity of the Mediterranean Sea: situation, problems and prospects for the future research. Marine Pollution Bulletin, 40 (5): 367-376.

Blanc, P.-L. 2002. The opening of the Plio-Quaternary Gibraltar Strait: assessing the size of a cataclysm. Geodinamica Acta, 15: 303-317.

Bouchet, P. \& Taviani, M. 1992. The Mediterranean deep-sea fauna: pseudopopulations of Atlantic species? Deep-sea Research, 39: 169-184

Bouillon, J., Medel, M.D., Pagos, F., Gili, J.-M., Boero, F. \& Gravili, C. 2004. Fauna of the Mediterranean Hydrozoa. Scientia Marina (Barcelona), Consejo Superior de Investigaciones Cientificas (Institut de Ciènces del Marina, Barcelona, Spain), 68(Suppl. 2): 5-449.

Butler, R.W.H., McClelland, E. \& Jones, R.E. 1999. Calibrating the duration and timing of the Messinian salinity crisis in the Mediterranean: linked tectonoclimatic signals in thrust-top basins in Sicily. Journal of the Geological Society, London, 156: 827-835.

Carnevale, G., Landini, W. \& Sarti, G. 2006. Mare versus Lago-mare: marine fishes and the Mediterranean environment at the end of the Messinian Salinity Crisis. Journal of the Geological Society, London, 163: 75-80.

Castradori, D. 1998. Calcareous nannofossil in the basal Zanclean of the eastern Mediterranean Sea: Remarks on paleoceanography and sapropel formation. Proceedings of the Ocean Drilling Program Scientific Results, 160: 113-123.

Cita, M.B. 1975. Studi sul Pliocene e gli strati di passagio del Miocene al Pliocene, VIII. Planktonic foraminiferal biozonation of the Mediterranean Pliocene deep sea record: a revision. Rivista Italia di Paleontologia e Stratigrafia, 81: 527-544.

Dale, B. 1992. Dinoflagellate contribution to the open ocean sediment flux. In: Honjo, S. (Ed.), Dinoflagellate contribution to the Deep Sea. Ocean Biocoenosis Series, 5. Woods Hole Oceanographic Institution, Woods Hole, Massachusetts, 1-32.

De Lange, G.J., van Santvoort, P.J.M., Langereis, C., et al. 1999. Palaeo-environmental variations in eastern Mediterranean sediments: A multidisciplinary approach in a prehistoric setting. Progress in Oceanography, 44: 369-386.

Diester-Haass, L., Robert, C. \& Chamley, H. 1998. Paleoproductivity and climate variations during sapropel deposition in the eastern Mediterranean Sea. Proceedings of the Ocean Drilling Program Scientific Results, 160: 227-248.

Domingues, V.S., Bucciarelli, G., Almada, V.C. \& Bernardi, G. 2005 Historical colonization and demography of the Mediterranean Damselfish, Chromis chromis. Molecular Ecology, 14 (13): 4051-4063.

Emig, C. \& Geistdoerfer, P. 2004. The Mediterranean deep-sea fauna: historical evolution, bathymetric variations and geographical changes. Carnets de Géologie/Notebooks on Geology. Maintenon, CG2004 A01 CCE PG: 1-10.

Esper, O., Zonneveld, K.A.F., Höll, C., et al. 2000. Reconstruction of palaeoceanographic conditions in the South Atlantic Ocean at the last two Terminations based on calcareous dinoflagellates. International Journal of Earth Sciences, 88 (4): 680-693.

Fauquette, S., Guiot, J. \& Suc, J.P. 1998. A method for climatic reconstruction of the Mediterranean Pliocene using pollen data. Palaeogeography, Palaeoclimatology, Palaeoecology, 144: 183-201.

Friedrich, O. \& Meier, K.J.S. 2003. Stable isotopic indication for cyst formation depth of Campanian/Maastrichtian calcareous dinoflagellates. Micropaleontology, 49 (4): 375-380.

Fütterer, D. 1977. Distribution of calcareous dinoflagellates in Cenozoic sediments of Site 366, Eastern North Atlantic. Initial Reports of the Deep Sea Drilling Project, US Government Printing Office, Washington, D.C., 41: 533-541.

Gottschling, M. \& Plötner, J. 2004. Secondary structure models of the nuclear internal transcribed spacer regions and 5.8S rRNA in Calciodinelloideae (Peridiniaceae) and other dinoflagellates. Nucleic Acids Research, 32 (1): 307-315.

Gottschling, M., Keupp, H., Plötner, J., Knop, R., Willems, H. \& Kirsch, M. 2005. Phylogeny of calcareous dinoflagellates as inferred from IST and ribosomal sequence data. Molecular Phylogenetics and Evolution, 36: 444-455.
Griffin, D.L. 1999. The late Miocene climate of northeastern Africa: unravelling the signals in the sedimentary succession. Journal of the Geological Society, London, 156: 817-826.

Hernández-Becerril, D.U. \& Bravo-Sierra, E. 2004. New records of planktonic dinoflagellates (Dinophyceae) from the Mexican Pacific Ocean. Botanica Marina, 47 (5): 417-423.

Hildebrand-Habel, T. \& Streng, M. 2003. Calcareous dinoflagellate associations and Maastrichtian-Tertiary climatic change in a high latitude core (ODP Hole 689B, Maud Rise, Weddell Sea). Palaeogeography, Palaeoclimatology, Palaeoecology, 197: 293-321.

Hildebrand-Habel, T. \& Willems, H. 1997. Calcareous dinoflagellate cysts from the Middle Coniacian to Upper Santonian chalk facies of Lägerdorf (N Germany). Courier Forschungsinstitut Senckenberg, 201: 177-199.

Hildebrand-Habel, T. \& Willems, H. 2000. Distribution of calcareous dinoflagellates from the Maastrichtian to early Miocene of DSDP Site 357 (Rio Grande Rise, western South Atlantic Ocean). International Journal of Earth Sciences, 88: 694-707.

Hildebrand-Habel, T., Willems, H. \& Versteegh, G.J.M. 1999. Variations in calcareous dinoflagellate associations from the Maastrichtian to Middle Eocene of the western South Atlantic Ocean (Sao Paulo Plateau, DSDP Leg 39, Site 356). Review of Palaeobotany and Palynology, 106(1-2): 57-87.

Hilgen, F.J. 1991. Astronomical calibration of Gauss to Matuyama sapropels in the Mediterranean and implication for the geomagnetic polarity time scale. Earth and Planetary Science Letters, 104: 226-244.

Höll, C. \& Kemle-von Mücke, S. 2000. Late Quaternary upwelling variations in the eastern equatorial Atlantic Ocean as inferred from dinoflagellate cysts, planktonic foraminifera, and organic carbon content. Quaternary Research, 54 (1): 58-67.

Höll, C., Zonneveld, K.A.F. \& Willems, H. 1998. On the ecology of calcareous dinoflagellates: The Quaternary Eastern Equatorial Atlantic. Marine Micropaleontology, 33(1-2): 1-25.

Höll, C., Karwath, B., Rühlemann, C., Zonneveld, K.A.F. \& Willems, H. 1999. Palaeoenvironmental information gained from calcareous dinoflagellates: the late Quaternary eastern and western tropical Atlantic Ocean in comparison. Palaeogeography, Palaeoclimatology, Palaeoecology, 146: 147-164.

Hsü, K.J. 1978. The Messinian salinity crisis. Naturwissenschaften (Historical Archive), 5(3): 151pp.

Hsü, K.J. \& Bernoulli, D. 1978. Genesis of the Tethys and the Mediterranean. Initial Reports of the Deep Sea Drilling Project, US Government Printing Office, Washington, D. C., 42: 943-949.

Hsü, K.J., Cita, M.B. \& Ryan, W.B.F. 1973. The origin of the Mediterranean evaporites. Initial Reports of the Deep Sea Drilling Project, US Government Printing Office, Washington, D.C., 13: $1203-1231$.

Hsü, K.J., Montadert, L., Bernoulli, D., et al. 1977. History of the Mediterranean salinity crisis. Nature, 267: 399-403.

Iaccarino, S.M., Castradori, D., Cita, M.B., et al. 1999. The MiocenePliocene boundary and the significance of the earliest Pliocene flooding in the Mediterranean. Memorie della Societa Geologica Italiana, 54: 109-131.

Janofske, D. 1996. Ultrastructure types in recent "Calcispheres". Bulletin de l'Institut océanographique, 14 (4): 295-303.

Janofske, D. \& Karwath, B. 2000. Oceanic calcareous dinoflagellates of the equatorial Atlantic Ocean: Cyst-theca relationship, taxonomy and aspects on ecology. In: Karwath, B. (Ed.), Ecological Studies on Living and Fossil Calcareous Dinoflagellates of the Equatorial and Tropical Atlantic Ocean. Berichte Fachbereich Geowissenschaften, Universität Bremen, 152: 94-136.

Karwath, B., Janofske, D. \& Willems, H. 2000. Spatial distribution of the calcareous dinoflagellate Thoracosphaera heimii in the upper water column of the tropical and equatorial Atlantic. International Journal of Earth Sciences, 88: 668-679.

Keogh, S.M. \& Butler, R.W.H. 1999. The Mediterranean water body in the late Messinian: interpreting the record from marginal basins on Sicily. Journal of the Geological Society, London, 156: 837-846.

Keupp, H. \& Kohring, R. 1993. Kalkige Dinoflagellatenzysten aus dem Obermiozän von El Medhi (Algerien). Berliner Geowisswissenschaftliche Abhandlungen, 9: 25-43. 
Keupp, H. \& Kohring, R. 1999. Kalkiger Dinoflagellatenzysten aus dem Obermiozän (NN 11) W von Rethymnon (Kreta). Berliner Geowissenschaftliche Abhandlungen, E30: 33-53.

Keupp, H. \& Versteegh, G. 1989. Ein neues Konzept für kalkige Dinoflagellaten-zysten der Subfamilie Orthopithonelloideae Keupp 1987. Berliner Geowissenschaftliche Abhandlungen, A106: 207-219.

Keupp, H., Bellas, S.M., Frydas, D. \& Kohring, R. 1994. Aghia Irini, ein Neogenprofil auf der Halbinsel Gramvoússa/NW-Kreta. Berliner Geowissenschaftliche Abhandlungen, E13: 469-481.

Kohring, R. 1993a. Kalkdinoflagellaten aus dem Mittel- und Obereozän von Jütland (Dänemark) und dem Pariser Becken (Frankreich) im Vergleich mit anderen Tertiär-Vorkommen. Berliner Geowissenschaftliche Abhandlungen, E6: 1-164.

Kohring, R. 1993b. Kalkdinoflagellaten-Zysten aus dem unteren Pliozän von E-Sizilien. Berliner Geowissenschaftliche Abhandlungen, E9: $15-23$.

Kohring, R. 1997. Calcareous dinoflagellate cysts from the Blue Clay formation (Serravalian, Late Miocene) of the Maltese Islands. Neues Jahrbuch, Geologisch-Paläontologische Mitteilungen, 3: 151-164.

Kohring, R., Gottschling, M. \& Keupp, H. 2005. Examples for character traits and palaeoecological significance of calcareous dinoflagellates. Paläontologische Zeitschrift, 79 (1): 79-91.

Kouwenhoven, T.J. 2000. Survival under stress: benthic foraminiferal patterns and Cenozoic biotic crises. Geologica Ultraiectina, 186. Faculteit Aardwetenschappen, Universiteit Utrecht, 206pp.

Kouwenhoven, T.J., Morigi, C., Negri, A., Giunta, S., Krijgsman, W. \& Rouchy, J.M. 2006. Paleoenvironmental evolution of the eastern Mediterranean during the Messinian: Constraints from integrated microfossil data of the Pissouri Basin (Cyprus). Marine Micropaleontology, 60 (1): 17-44.

Krijgsman, W., Langereis, C.G., Zachariasse, W.J., et al. 1999. Late Neogene evolution of the Taza-Guercif Basin (Rifian Corridor, Morocco) and implications for the Messinian salinity crisis. Marine Geology, 153: 147-160.

Krijgsman, W., Blanc-Valleron, M.-M., Flecker, R., et al. 2002. The onset of the Messinian salinity crisis in the eastern Mediterranean (Pissouri Basin, Cyprus). Earth Planetary Science Letters, 194: 299-300.

Lofi, C.J., Gorini, C., Berné, S., Clauzon, G., Reis, A.T.D., Ryan, W.B.F. \& Steckler, M.S. 2005. Erosional processes and paleoenvironmental changes in the Western Gulf of Lions (SW France) during the Messinian Salinity. Marine Geology, 217(1-2): 1-30.

Logan, A., Bianchi, C.N., Morri, C. \& Zibrowius, H. 2004. The present-day Mediterranean brachiopod fauna: diversity, life habits, biogeography and paleobiogeography. Scientia Marina, 68 (1): 167-170.

Loget, N., Davy, P. \& Van Den Driessche, J. 2006. Mesoscale fluvial erosion parameters deduced from modelling the Mediterranean Sea level drop during the Messinian (late Miocene). Journal of Geophysical Research, 111: FO3005.

Manzi, V., Lugli, S., Lucchi, F.R. \& Roveri, M. 2005. Deep-water clastic evaporites deposition in the Messinian Adriatic foredeep (northern Apennines, Italy): did the Mediterranean ever dry out? Sedimentology, 52: 875-902.

Matano, F., Barbieri, M., Di Nocera, S. \& Torre, M. 2005. Stratigraphy and strontium geochemistry of Messinian evaporite-bearing successions of the southern Apennines foredeep, Italy: implications for the Mediterranean "salinity crisis" and regional. Palaeogeography. Palaeogeography, Palaeoclimatology, Palaeoecology, 217(1-2): 87-114.

Meier, K.J.S. \& Willems, H. 2003. Calcareous dinoflagellate cysts from surface sediments of the Mediterranean Sea: distribution patterns and influence of main environmental gradients. Marine Micropaleontology, 48: 321-354.

Meier, K.J.S., Janofske, D. \& Willems, H. 2002. New calcareous dinoflagellates (Calciodinelloideae) from the Mediterranean Sea. Journal of Phycology, 38: 602-615.

Meier, K.J.S., Zonneveld, K.A.F., Kasten, S. \& Willems, H. 2004. Different nutrient sources forcing increased productivity during eastern Mediterranean S1 sapropel formation as reflected by calcareous dinoflagellate cysts. Paleoceanography, 19: $1-12$ (doi10.1029/2003PA000895).
Meijer, P.Th. \& Krijgsman, W. 2005. A quantitative analysis of the desiccation and re-filling of the Mediterranean during the Messinian Salinity Crisis. Earth and Planetary Science Letters, 240(2): 510-520.

Orszag-Sperber, F., Rouchy, J.M. \& Elion, P. 1989. The sedimentary expression of regional tectonic events during the Miocene-Pliocene transition in the southern Cyprus basins. Geological Magazine, 126(3): 291-299.

Orszag-Sperber, F., Rouchy, J.-M. \& Blanc-Valleron, M.-M. 2000. La transition Messinien-Pliocène en Méditerranée orientale (Chypre): la période du Lago-Mare et sa signification. Earth and Planetary Sciences, 331: 483-490.

Robertson, A.H.F., Eaton, S.E., Folloes, E.J. \& Payne, A.S. 1995. Sedimentology and depositional processes of Miocene evaporites from Cyprus. Terra Nova, 7: 233-254.

Rossignol-Strick, M. 1985. Mediterranean Quaternary sapropels, an immediate response of the African monsoon to variation of insolation. Palaeogeography, Palaeoclimatology, Palaeoecology, 49: 237-263.

Rouchy, J.M., Orszag-Sperber, F., Blanc-Valleron, M.-M., Pierre, C., Rivière, M., Combourieu-Nebout, N. \& Panayides, I. 2001. Paleoenvironmental Changes at the Messinian-Pliocene Boundary in the Eastern Mediterranean (Southern Cyprus basins): Significance of the Messinian Lago-Mare. Sedimentological Geology, 145: 93-117.

Seidenkrantz, M.-S., Kouwenhoven, T.J., Jorissen, F.J., Shackleton, N.J. \& van der Zwaan, G.J. 2000. Benthic foraminifera as indicators of changing Mediterranean-Atlantic water exchange in the late Miocene. Marine Geology, 163: 387-407.

Spezzaferri, S., Cita, M.-B. \& McKenzie, J.A. 1998. The Miocene/ Pliocene boundary in the eastern Mediterranean: Results from sites 967 and 969. Proceedings of the Ocean Drilling Program, Scientific Results, 160: 9-28.

Steenbrink, J., Hilgen, F.J., Krijgsman, W., Wijbrans, J.R. \& Meulenkamp, J.E. 2006. Late Miocene to Early Pliocene depositional history of the intramontane Florina-Ptolemais-Servia Basin, NW Greece: Interplay between orbital forcing and tectonics. Palaeogeography, Palaeoclimatology, Palaeoecology, 238 (1-4): 151-178.

Streng, M., Hildebrand-Habel, T. \& Willems, H. 2002. Revision of the genera Sphaerodinella Keupp and Versteegh, 1989 and Orthopithonella Keupp in Keupp and Mutterlose, 1984 (Calciodinelloideae, calcareous dinoflagellate cysts). Journal of Paleontology, 76: 397-407.

Streng, M., Hildebrand-Habel, T. \& Willems, H. 2004. Long-term evolution of calcareous dinoflagellate associations since the Late Cretaceous: comparison of a high- and a low-latitude core from the Indian Ocean. Journal of Nannoplankton Research, 26: 13-45.

Tanimura, Y. \& Shimada, C. 2004. Calcareous dinoflagellates from a northwestern Pacific sediment trap and their paleoceanographic implications. Micropaleontology, 50: 343-356.

Tay, P.L., Lonergan, L., Warner, M., Jones, K.A. \& The IMERSE Working Group 2002. Seismic investigation of thick evaporite deposits on the central and inner unit of the Mediterranean Ridge accretionary complex. Marine Geology, 186: 167-194.

Van der Laan, E., Snel, E., de Kaenel, E., Hilgen, F.J. \& Krijgsman, W. 2006. No major deglaciation across the Miocene-Pliocene boundary: Integrated stratigraphy and astronomical tuning of the Loulja sections (Bou Regreg area, NW Morocco). Paleoceanography, 21: 1-27.

Versteegh, G.J.M. 1993. New Pliocene and Pleistocene calcareous dinoflagellate cysts from southern Italy and Crete. Review of Palaeobotany and Palynology, 78: 353-380.

Vink, A. 2004. Calcareous dinoflagellate cysts in South and equatorial Atlantic surface sediments: diversity, distribution, ecology and potential for palaeoenvironmental reconstruction. Marine Micropaleontology, 50: 43-88.

Vink, A., Zonneveld, K.A.F. \& Willems, H. 2000. Distributions of calcareous dinoflagellates in surface sediments of the western equatorial Atlantic, and their potential use in palaeoceanography. Marine Micropaleontology, 38: 149-180.

Vink, A., Brune, A., Höll, C., Zonneveld, K.A.F. \& Willems, H. 2002. On the response of calcareous dinoflagellates to oligotrophy and stratification of the upper water column in the equatorial Atlantic Ocean. Palaeography, Palaeoclimatology, Palaeoecology, 178: 53-66.

Vink, A., Baumann, K.-H., Boeckel, B., et al. 2003. Coccolithophorid and dinoflagellate synecology in the South and Equatorial Atlantic: 
Improving the palaeoecological significance of phytoplanktonic microfossils. In: Wefer, G., Mulitza, S. \& Rathmeyer, V. (Eds), The South Atlantic in the Late Quaternary: Reconstruction of Material Budgets and Current Systems. Springer, Heidelberg, New York, 101-120.

Wade, B.S. \& Bown, P.R. 2005. Calcareous nannofossils in extreme environments: The Messinian Salinity Crisis, Polemi Basin, Cyprus. Palaeogeography, Palaeoclimatology, Palaeoecology, 233 (3-4): 271-286.

Wehausen, R. \& Brumsack, H.J. 1998. The formation of Pliocene Mediterranean sapropels: Constraints from high-resolution mayor and minor element studies. Proceedings of the Ocean Drilling Program, Scientific Results, 160: 207-217.

Wendler, I., Zonneveld, K.A.F. \& Willems, H. 2002a. Calcareous cyst-producing dinoflagellates: ecology and aspects of cyst preservation in a highly productive oceanic region. In: Clift, P.D., Kroon, D., Geadicke, C. \& Craig, J. (Eds), The Tectonic and Climatic Evolution of the Arabian Sea Region. Geological Society, London, Special Publications, 195: 317-340.

Wendler, I., Zonneveld, K.A.F. \& Willems, H. 2002b. Oxygen availability effects on early diagenetic calcite dissolution in the Arabian Sea as inferred from calcareous dinoflagellate cysts. Global and Planetary Change, 34: 219-239.

Wendler, I., Zonneveld, K.A.F. \& Willems, H. 2002c. Production of calcareous dinoflagellate cysts in response to monsoon forcing off Somalia: a sediment trap study. Marine Micropaleontology, 46: 1-11.
Ziveri, P., Rutten, A., de Lange, G., Thomson, J. \& Corselli, C. 2000. Present-day coccolith fluxes recorded in central Eastern Mediterranean sediment traps and surface sediments. Palaeogeography, Palaeoclimatology, Palaeoecology, 158: 175-195.

Zonneveld, K.A.F. 2004. Potential use of stable oxygen isotope composition of Thoracosphaera heimii for upper water column (thermocline) temperature reconstruction. Marine Micropaleontology, $\mathbf{5 0}$ (3/4): 307-317.

Zonneveld, K.A.F., Höll, C., Janofske, D., Karwath, B., Kerntopf, B., Rühlemann, C. \& Willems, H. 1999. Calcareous dinoflagellates as palaeo-environmental tools. In: Fischer, G. \& Wefer, G. (Eds), Use of proxies in Paleoceanography: Examples from the South Atlantic. Springer, Berlin, 145-164.

Zonneveld, K.A.F., Brune, A. \& Willems, H. 2000. Spatial distribution of calcareous dinoflagellates in surface sediments of the South Atlantic Ocean between $13^{\circ} \mathrm{N}$ and $36^{\circ} \mathrm{S}$. Review of Palaeobotany and Palynology, 111: 197-223.

Zonneveld, K.A.F., Versteegh, G.J.M. \& De Lange, G.J. 2001. Palaeoproductivity and post-depositional aerobic organic matter decay reflected by dinoflagellate cyst assemblages of the Eastern Mediterranean S1 sapropel. Marine Geology, 172: 181-195. 